\title{
Norm violators as threats and opportunities: The many faces of deviance in groups
}

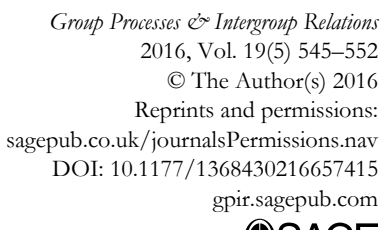

@SAGE

\section{John M. Levine ${ }^{1}$ and José M. Marques ${ }^{2,3}$}

\begin{abstract}
Group researchers have long been interested in how group members respond to deviance, defined as the violation of prescriptive norms about how members should think, feel, or act. Valuable perspectives on reaction to deviance have been offered by scholars in several disciplines, including social psychology, evolutionary psychology, and sociology. Most of the theoretical and empirical work on reaction to deviance assumes that this behavior has negative consequences for group welfare and hence elicits efforts designed to reduce or eliminate it, including the threat or use of punishment. However, there is increasing interest in the other side of the coin, namely cases in which deviance has positive consequences for group welfare and hence is tolerated or even celebrated. In addition, researchers are also devoting increased attention to the causes of deviance, that is, the reasons why some group members choose to violate prescriptive norms even though doing so may elicit punishment. The papers in this Special Issue, which investigate deviance in a wide range of situations, illustrate cutting-edge work on each of these themes.
\end{abstract}

\section{Keywords}

deviance, groups, norms, social identity

Paper received 27 April 2016; revised version accepted 4 June 2016.

All groups-large and small, formal and informal, short-term and long-term-possess norms, which can be defined as "rules and standards that are understood by members of a group, and that guide and/or constrain social behavior without the force of laws" (Cialdini \& Trost, 1998, p. 152). Of particular relevance for our purposes are prescriptive (injunctive) norms, which define how group members should behave and which are enforced by the promise or delivery of rewards and punishments. Not surprisingly, most group members comply with prescriptive norms most of the time. However, there are

\footnotetext{
${ }^{1}$ University of Pittsburgh, USA

${ }^{2}$ University of Porto, Portugal

${ }^{3}$ University of Lisbon, Portugal

Corresponding author:

John M. Levine, Department of Psychology, University of

Pittsburgh, 516 LRDC Bldg., 3939 O’Hara, Pittsburgh,

PA 15260, USA.

Email: jml@pitt.edu
} 
important exceptions to this general rule. Group members sometimes deviate from such norms, and doing so can have substantial consequences-positive or negative-for both the deviate and the group as a whole (see Hogg, Fielding, \& Darley, 2005). These exceptions are the focus of this Special Issue.

\section{A Short History of Prior Work on Deviance}

Traditional analyses of deviance in social psychology focused on how groups respond to the presence of deviates in their midst. Moreover, these analyses assumed that deviance generally has negative consequences for group welfare and hence elicits behavior designed to reduce or eliminate it. This perspective is consistent with evolutionary analyses, which argue that humans have evolved "mechanisms to identify individuals who threaten or hinder successful group functioning, to label them as such, to motivate group members to withhold group benefits from them, and to separate such individuals from the group if necessary" (Neuberg, Smith, \& Asher, 2000 , p. 36). An early example of the "deviance is bad" perspective is Festinger's (1950) analysis of group responses to opinion deviance. According to Festinger, people who challenge group consensus are problematical because they threaten other members' desire to validate opinions not based on physical reality (social reality motive) or their desire to achieve collective goals (group locomotion motive). The presence of an opinion deviate produces uniformity pressures in the group, and the resulting communication between the group and deviate can resolve the disagreement in two ways - the deviate can move toward the group's position or vice versa. In addition, the group can redefine its boundaries by rejecting the deviate. This influential model, which was extended by Festinger (1954) and elaborated by others (e.g., Collins \& Raven, 1969; Israel, 1956), stimulated substantial research designed to identify factors that influence the type and magnitude of responses directed toward opinion deviates (see Levine, 1989 and Levine \&
Kerr, 2007, for reviews). Much of this work used experimental paradigms in which opinion deviates engaged in actual or simulated interactions with other members.

More recent analyses of reaction to deviance, based on the social identity approach, also assume that deviates are threatening and elicit negative reactions from other group members. However, social identity analyses downplay group members' interaction and behavioral interdependence in favor of their collective selfdefinition as members of an ingroup that has a (more or less) competitive relationship with an outgroup. An influential line of work in this tradition involves the "black sheep effect" (BSE), which demonstrates that ingroup deviates are evaluated more negatively than outgroup members holding the same position (and ingroup conformers are evaluated more positively than outgroup members holding the same position) (e.g., Marques \& Paez, 1994; Marques, Yzerbyt, \& Leyens, 1988). Extending and elaborating the BSE, subjective group dynamics theory (SGDT) assumes that group members are motivated to create or maintain a positive social identity, which depends on both the positive distinctiveness of their ingroup vis-à-vis outgroups and the relative validity of their ingroup's prescriptive norms. This motivation, in turn, produces especially positive evaluations of ingroup conformers and especially negative evaluations of ingroup deviates (Marques, Abrams, Paez, \& Martinez-Taboada, 1998; Marques, Abrams, \& Serodio, 2001; Pinto, Marques, Levine, \& Abrams, 2010, 2016).

Most of the work on reaction to deviance inspired by SGDT has focused on cases in which group members' social identity is increased by responding negatively to deviates who oppose the group's modal position. However, SGDT has also been applied to cases in which members' social identity is enhanced by responding positively to deviates who take a more extreme position than the ingroup, thereby emphasizing the distinctiveness of the ingroup vis-à-vis an outgroup (e.g., Abrams, Marques, Bown, \& Dougill, 2002; Abrams, 
Marques, Bown, \& Henson, 2000). The notion that both rejection and acceptance of deviates can yield benefits to group members is consistent with major premises of the "functionalist" school of sociology (see Marques, Paez, \& Abrams, 1998). For example, Durkheim $(1895 / 1966)$ argued that the presence of deviates can affirm a group's cultural values and norms, clarify its moral boundaries, and promote social unity among its members. According to Durkheim, by defining what the group does not stand for, deviates help other members understand what it does stand for and strengthen their cohesion. Although these positive consequences are seen as arising from collective rejection of deviates, some sociologists suggest that a group can also benefit from the opposite response, namely collective tolerance of deviates. In the latter case, rather than being proscribed, deviance may be permitted or even preferred (e.g., because tolerance is a group value, because the deviate facilitates group performance; e.g., Coser, 1962; Dentler \& Erickson, 1959).

Several recent lines of social psychological research on deviance view it as a natural and often positive force in group life (see Jetten \& Hornsey, 2011). Perhaps the most influential example is work on minority influence, which was initially stimulated by Moscovici's argument that deviates can serve as critical catalysts of social change, or innovation (e.g., Moscovici, 1976, 1980; Moscovici \& Faucheux, 1972). Moscovici's basic premise is that minorities can produce change to the extent that they stimulate conflict, which motivates majority members to attend to and process their arguments. His contention that small (and powerless) minorities can sometimes influence larger majorities stimulated a great deal of theoretical attention (e.g., Crano, 2010; Martin \& Hewstone, 2008; Nemeth, 1986; Perez \& Mugny, 1996) as well as a large empirical literature investigating the conditions under which minorities are effective agents of social influence. Taken as a whole, this body of work challenged many of the premises underlying Festinger's and related analyses of reaction to deviance and revolutionized how social psychologists think about influence processes in groups (see Levine \& Tindale, 2015 and Martin \& Hewstone, 2010, for reviews).

Our discussion so far has focused on why and how groups respond to members who exhibit deviance of one form or another. An equally interesting question is why some members challenge group norms in the first place, particularly in situations where such behavior is likely to elicit negative responses. Although less work has been done on the motives underlying deviance than on the reactions it elicits, in recent years these motives have become a more active research focus. Among the motives identified as important are either disengagement from a group or engagement with it, strong moral convictions, desire to express individuality or uniqueness, and desire to obtain tangible rewards (Jetten \& Hornsey, 2014).

\section{Overview of Papers in the Special Issue}

Reflecting the greater attention paid to the consequences than the causes of deviance, the papers in this Special Issue focus primarily on the mechanisms underlying group members' reactions to people who deviate from prescriptive norms. ${ }^{1}$ We adopt a broad definition of deviance as "behavior that challenges an explicit or implicit norm about how group members should think, feel, or act." Thus, papers in the Special Issue analyze such diverse forms of deviance as performing poorly or cheating on a group task, assigning rewards to group members using a nonnormative decision rule, withholding or distorting information, showing racial bias in selecting job candidates, challenging a team's task strategy, advocating rule breaking in work settings, dissenting from group consensus on opinion issues, exposing group misconduct to outsiders, and exhibiting principled dissent (moral rebellion).

Prior analyses of reaction to deviance have assumed that (a) group members' perception of 
how a deviate's behavior affects their goal attainment is a critical determinant of their responses to that individual and (b) this perception is heavily influenced by the characteristics of both parties (e.g., Levine, 1989; Levine, Choi, \& Moreland, 2003; Levine \& Moreland, 2002). The papers in this Special Issue are consistent with this general perspective but extend and elaborate it in new and interesting ways. In summarizing the papers, we first discuss those that focus primarily on characteristics of the deviate and then discuss those that emphasize characteristics of other group members. We use the term "characteristics" broadly to include behaviors, group affiliations, attributed motives, roles and statuses, and psychological states (e.g., group identification, feelings of control, dissonance, imagined reproach).

Three papers analyzed how characteristics of deviates influenced the reactions they received from other group members. In their paper on "whistle-blowers" and "leakers," Kimberly Rios and Zig Ingraffia (2016) investigated how the motives attributed to people who expose group misconduct affect the harshness of the judgments they receive from other members. Their results indicated that whistle-blowers were more likely to be seen as motivated by moral and collective concerns than were leakers, which in turn produced more lenient judgments of whistle-blowers. In their paper on membership role and subjective group dynamics, Isabel Pinto, José Marques, John Levine, and Dominic Abrams (2016) examined how a target person's ingroup versus outgroup affiliation, full member versus marginal member role in the group, and normative versus deviant opinion regarding a prescriptive norm affected other members' evaluations of the target and endorsement of the norm. They found that when a deviant ingroup full member was paired with a normative ingroup full member, these members received highly polarized negative and positive evaluations, respectively, and the norm was highly endorsed. However, when a deviant ingroup full member was paired with a normative ingroup marginal member, the deviant was derogated least and his/her position was endorsed most. Finally, in their paper on group utilization of a dissenting newcomer's knowledge, Aimee Kane and Floor Rink (2016) investigated how the language (integrating vs. differentiating pronouns) that newcomers used in suggesting a novel task strategy affected group members' receptivity to this strategy. Their results indicated that newcomers with permanent (but not temporary) future prospects were more successful when they used integrating rather than differentiating language.

Four papers analyzed how characteristics of other group members influenced their reactions to deviates. In their paper on how norm violations shape social hierarchies, Eftychia Stamkou, Gerben van Kleef, Astrid Homan, and Adam Galinsky (2016) assessed how group members' hierarchical position affected the likelihood that they would grant power to a person who violated conventional norms. The researchers found that higher ranked group members (based on trait verticality but not state verticality) showed a stronger preference for norm followers over norm violators than did lower ranked members, presumably because higher ranked members felt more threatened by norm violators' challenge to the status quo. In their paper assessing the impact of deviance on social exclusion and leaving, Lara Ditrich and Kai Sassenberg (2016) investigated how a person's severe deviation from group norms affected other members' tendencies to exclude the deviate from the group and to leave the group themselves. They found that exclusion was mediated by members' perception that the deviate had subverted or undermined the group's essence and thereby weakened their identification with the group. In contrast, leaving depended on members' perception that they had low situational control, based on others' alleged acceptance of the deviation. In their paper on the behavioral benefits of other people's deviance, Brian Gunia and Sun Young Kim (2016) studied the relationships between an ingroup member's deviance, other group members' experience of vicarious dissonance, and their subsequent work effort. They 
found that such deviance elicited dissonance in other group members, which in turn increased their work effort. Moreover, the tendency to work harder after observing deviance was weaker when the deviate was an outgroup rather than an ingroup member. Finally, in their paper on principled deviance and moral threat, Kieran O'Connor and Benoit Monin (2016) analyzed the psychological mechanism(s) underlying the finding that moral rebels-people who take a principled stand in a morally problematic situation-are rejected by those who did not take this stand themselves. The researchers found that such rejection was affected by both the rebel's verbal condemnation of "immoral" behavior and refusal to engage in this behavior and that the key element in rejection was imagined moral reproach from the rebel.

The papers discussed so far all focused on the reactions that deviates elicited from other group members rather than on the reasons why some people deviated from group norms in the first place. However, one paper in the Special Issue focused on the latter question, and a second (discussed above) touched on it. In their paper on collective identification, collective angst, and dissent, Darcy Dupuis, Michael Wohl, Dominic Packer, and Nassim Tabri (2016) examined factors that motivated people to engage in behavior designed to protect their ingroup. Their research indicated that members who disagreed with their group's position on a controversial issue were most likely to dissent when (a) they believed the position threatened the group's vitality or existence (i.e., elicited collective angst) and (b) they identified strongly with the group. Moreover, Kimberly Rios and Zig Ingraffia (2016), in their paper on whistle-blowers and leakers, included a study assessing how receiving one or the other label affected participants' selfreported motives and inclination to expose group misconduct. They found that participants who received the whistle-blower, as opposed to leaker, label saw themselves as having greater moral concern, which mediated their greater willingness to reveal negative information about the group.
We noted earlier that, although deviates are often perceived as inhibiting group members' ability to attain valued goals of one sort or another, they can also facilitate goal attainment in certain cases. Consistent with this latter possibility, several papers in the Special Issue examined "positive" forms of deviance. These include Rios and Ingraffia's (2016) whistle-blowers, who, though they initially cause problems for the group, can stimulate changes that improve the group in the long run; Kane and Rink's (2016) newcomers, who bring potentially useful knowledge that can enhance group performance; Gunia and Kim's (2016) norm violators, who stimulate other members to work hard; O'Connor and Monin's (2016) moral rebels, who, though often rejected, may liberate others from social pressure (cf. Allen, 1975; Monin \& O'Connor, 2011); and Dupuis et al.'s (2016) dissenters, whose behavior can serve a protective group function.

\section{Conclusion}

Although deviance has remained an important topic of social psychological inquiry for some 65 years, the major questions and assumptions driving this work have changed substantially over this period. One major change involves the motives that deviates are assumed to threaten. Whereas initial work focused on the threat that deviates pose to other members' desire to satisfy social reality and group locomotion motives, subsequent work emphasized deviates' ability to undermine other members' desire to maintain a positive social identity. A second major change involves increased attention to cases in which deviates play a positive, rather than a negative, role in group life by facilitating, rather than inhibiting, other members' goal attainment. Finally, a third major change involves increased interest in factors that motivate individuals to engage in behaviors that depart from group norms, even when doing so incurs the risk of hostility and punishment from other members.

The papers in this Special Issue, which reflect all three of these trends, illustrate the continued 
vitality of deviance as a research focus in social psychology. Because much remains to be learned about the causes and consequences of this important group phenomenon, we are optimistic that it will continue to inspire exciting theoretical and empirical work for many years to come.

\section{Funding}

The author(s) received no financial support for the research, authorship, and/or publication of this article.

\section{Note}

1. We do not include research focusing on how deviates respond to the (often negative) treatment they expect to receive or actually receive from other group members. For those interested in this issue, two large literatures are particularly relevant. One involves conformity to group pressure, that is, the tendency for a numerical minority to change its position toward that of a numerical majority (see Allen, 1965, 1975; Levine \& Tindale, 2015). The second involves responses to social exclusion, including ostracism (see Abrams, Hogg, \& Marques, 2005; Butera \& Levine, 2009; Levine \& Kerr, 2007; Williams, Forgas, \& von Hippel, 2005).

\section{References}

Abrams, D., Hogg, M. A., \& Marques, J. M. (Eds.) (2005). The social psychology of inclusion and exclusion. New York, NY: Psychology Press.

Abrams, D., Marques, J. M., Bown, N., \& Dougill, M. (2002). Anti-norm and pro-norm deviance in the bank and on the campus: Two experiments on subjective group dynamics. Group Processes and Intergroup Relations, 5, 163-182. doi:10.1177/1368430202005002922

Abrams, D., Marques, J. M., Bown, N., \& Henson, M. (2000). Pro-norm and anti-norm deviance within and between groups. Journal of Personality and Social Psychology, 78, 906-912. doi:10.1037/00223514.78.5.906

Allen, V. L. (1965). Situational factors in conformity. In L. Berkowitz (Ed.), Advances in experimental social psychology (Vol. 2, pp. 133-175). New York, NY: Academic Press.

Allen, V. L. (1975). Social support for nonconformity. In L. Berkowitz (Ed.), Advances in experimental social psychology (Vol. 8, pp. 1-43). New York, NY: Academic Press.
Butera, F., \& Levine, J. M. (Eds.). (2009). Coping with minority status: Responses to exclusion and inclusion. New York, NY: Cambridge University Press.

Cialdini, R. B., \& Trost, M. R. (1998). Social influence: Social norms, conformity, and compliance. In D. Gilbert, S. Fiske, \& G. Lindzey (Eds.), The handbook of social psychology (4th ed., Vol. 2, pp. 151192). Boston, MA: McGraw-Hill.

Collins, B. E., \& Raven, B. H. (1969). Group structure: Attraction, coalitions, communication, and power. In G. Lindzey \& E. Aronson (Eds.), The handbook of social psychology (2nd ed., Vol. 4, pp. 102-204). Reading, MA: Addison-Wesley.

Coser, L. A. (1962). Some functions of deviant behavior and normative flexibility. American Journal of Sociology, 68, 172-181. doi:10.1086/223307

Crano, W. D. (2010). Majority and minority influence in attitude formation and attitude change: Context/categorization-leniency contract theory. In R. Martin \& M. Hewstone (Eds.), Minority influence and innovation: Antecedents, processes and consequences (pp. 53-77). New York, NY: Psychology Press.

Dentler, R. A., \& Erikson, K. T. (1959). The functions of deviance in groups. Social Problems, 7, 98-107. doi:10.1525/sp.1959.7.2.03a00010

Ditrich, L., \& Sassenberg, K. (2016). It's either you or me! Impact of deviations on social exclusion and leaving. Group Processes \& Intergroup Relations, 19, 630-652.

Dupuis, D., Wohl, M., Packer, D., \& Tabri, N. (2016). To dissent and protect: Stronger collective identification increases willingness to dissent when group norms evoke collective angst. Group Processes \& Intergroup Relations, 19, 694-710.

Durkheim, E. (1966). The rules of sociological method (S. Solovay \& J. Mueller, Trans.). New York, NY: Free Press. (Original work published 1895)

Festinger, L. (1950). Informal social communication. Psychological Review, 57, 271-282. doi:10.1037/ h0056932

Festinger, L. (1954). A theory of social comparison processes. Human Relations, 7, 117-140. doi:10.1177/001872675400700202

Gunia, B., \& Young Kim, S. Y. (2016). The behavioral benefits of other people's deviance. Group Processes \& Intergroup Relations, 19, 653-675.

Hogg, M. A., Fielding, K. S., \& Darley, J. (2005). Fringe dwellers: Processes of deviance and marginalization in groups. In D. Abrams, M. A. Hogg, \& J. M. Marques (Eds.), The social psychology of inclusion and exclusion (pp. 191-210). New York, NY: Psychology Press. 
Israel, J. (1956). Self-evaluation and rejection in groups: Three experimental studies and a conceptual outline. Uppsala, Sweden: Almqvist \& Wiksell.

Jetten, J., \& Hornsey, M. J. (Eds.). (2011). Rebels in groups: Dissent, deviance, difference, and defiance. Malden, MA: Wiley-Blackwell.

Jetten, J., \& Hornsey, M. J. (2014). Deviance and dissent in groups. Annual Review of Psychology, 65, 461485. doi:10.1146/annurev-psych-010213-115151

Kane, A., \& Rink, F. (2016). When and how groups utilize dissenting newcomer knowledge: Newcomers' future prospects condition the effect of language-based identity strategies. Group Processes \& Intergroup Relations, 19, 591-607.

Levine, J. M. (1989). Reaction to opinion deviance in small groups. In P. B. Paulus (Ed.), Psychology of group influence (2nd ed., pp. 187-231). Hillsdale, NJ: Erlbaum.

Levine, J. M., Choi, H.-S., \& Moreland, R. L. (2003). Newcomer innovation in work teams. In P. B. Paulus \& B. A. Nijstad (Eds.), Group creativity: Innovation through collaboration (pp. 202-224). New York, NY: Oxford University Press.

Levine, J. M., \& Kerr, N. L. (2007). Inclusion and exclusion: Implications for group processes. In A. W. Kruglanski \& E. T. Higgins (Eds.), Social psychology: Handbook of basic principles (2nd ed., pp. 759-784). New York, NY: Guildford Press.

Levine, J. M., \& Moreland, R. L. (2002). Group reactions to loyalty and disloyalty. In S. R. Thye \& E. J. Lawler (Eds.), Group cobesion, trust and solidarity: Advances in group processes (Vol. 19, pp. 203-228). Oxford, UK: Elsevier Science.

Levine, J. M., \& Tindale, R. S. (2015). Social influence in groups. In M. Mikulincer, P. R. Shaver, J. F. Dovidio, \& J. A. Simpson (Eds.), APA handbook of personality and social psychology (Vol. 2, Group processes pp. 3-34). Washington, DC: American Psychological Association.

Marques, J. M., Abrams, D., Paez, D., \& MartinezTaboada, C. (1998). The role of categorization and ingroup norms in judgments of groups and their members. Journal of Personality and Social Psychology, 75, 976-988. doi:10.1037/0022-3514.75.4.976

Marques, J. M., Abrams, D., \& Serodio, R. G. (2001). Being better by being right: Subjective group dynamics and derogation of in-group deviants when generic norms are undermined. Journal of Personality and Social Psychology, 81, 436-447. doi: 10.1037

Marques, J. M., \& Paez, D. (1994). The "black sheep effect": Social categorization, rejection of ingroup deviates, and perception of group variability. European Review of Social Psychology, 5, 37-68. doi:10.1080/14792779543000011

Marques, J. M., Paez, D., \& Abrams, D. (1998). Social identity and intragroup differentiation as subjective social control. In S. Worchel, J. F. Morales, D. Paez, \& J.-C. Deschamps (Eds.), Social identity: International perspectives (pp. 124-142). London, UK: Sage.

Marques, J. M., Yzerbyt, V. Y., \& Leyens, J.-P. (1988). The "black sheep effect": Extremity of judgments towards ingroup members as a function of group identification. European Journal of Social Psychology, 18, 1-16. doi:10.1002/ ejsp.2420180102

Martin, R., \& Hewstone, M. (2008). Majority versus minority influence, message processing, and attitude change: The source-context-elaboration model. In M. P. Zanna (Ed.), Advances in experimental social psychology (Vol. 40, pp. 237-326). San Diego, CA: Elsevier.

Martin, R., \& Hewstone, M. (Eds.). (2010). Minority influence and innovation: Antecedents, processes and consequences. New York, NY: Psychology Press.

Monin, B., \& O'Connor, K. (2011). Reactions to defiant deviants: Deliverance or defensiveness? In J. Jetten \& M. J. Hornsey (Eds.), Rebels in groups: Dissent, deviance, difference, and defiance (pp. 261-280). Malden, MA: Wiley-Blackwell.

Moscovici, S. (1976). Social influence and social change. London, UK: Academic Press.

Moscovici, S. (1980). Toward a theory of conversion behavior. In L. Berkowitz (Ed.), Advances in experimental social psychology (Vol. 13, pp. 209-239). New York, NY: Academic Press.

Moscovici, S., \& Faucheux, C. (1972). Social influence, conformity bias, and the study of active minorities. In L. Berkowitz (Ed.), Advances in experimental social psychology (Vol. 6, pp. 149-202). New York, NY: Academic Press.

Nemeth, C. J. (1986). Differential contributions of majority and minority influence. Psychological Review, 93, 23-32. doi:10.1037/0033-295x.93.1.23

Neuberg, S. L., Smith, D. M., \& Asher, T. (2000). Why people stigmatize: Toward a biocultural framework. In T. F. Heatherton, R. E. Kleck, M. R. Hebl, \& J. G. Hull (Eds.), The social psychology of stigma (pp. 31-61). New York, NY: Guilford Press.

O’Connor, K., \& Monin, B. (2016). When principled deviance becomes moral threat: Testing alternative mechanisms for the rejection of moral 
rebels. Group Processes \& Intergroup Relations, 19, 676-693.

Pérez, J. A., \& Mugny, G. (1996). The conflict elaboration theory of social influence. In E. H. Witte \& J. H. Davis (Eds.), Understanding group behavior: Small group processes and interpersonal relations (Vol. 2, pp. 191-210). Mahwah, NJ: Erlbaum.

Pinto, I. R., Marques, J. M., Levine, J. M., \& Abrams, D. (2010). Membership status and subjective group dynamics: Who triggers the black sheep effect? Journal of Personality and Social Psychology, 99, 107-119. doi:10.1037/a0018187

Pinto, I. R., Marques, J. M., Levine, J. M., \& Abrams, D. (2016). Membership role and subjective group dynamics: Impact on evaluative intragroup differentiation and commitment to prescriptive norms. Group Processes \& Intergroup Relations, 19, 570-590.

Rios, K., \& Ingraffia, Z. (2016). Judging the actions of "whistle-blowers" versus "leakers": Labels influence perceptions of dissenters who expose group misconduct. Group Processes \& Intergroup Relations, 19, 553-569.

Stamkou, E., van Kleef, G., Homan, A., \& Galinsky, A. (2016). How norm violations shape social hierarchies: Those who stand on top block norm violators from rising up. Group Processes \& Intergroup Relations, 19, 608-629.

Williams, K. D., Forgas, J. P., \& von Hippel, W. (Eds.). (2005). The social outcast: Ostracism, social exclusion, rejection, and bullying. New York, NY: Psychology Press. 